\title{
Development of the Canadian Emergency Department Diagnosis Shortlist
}

\author{
Bernard Unger, MD; ${ }^{*}$ Marc Afilalo, MD; ${ }^{*}$ Jean François Boivin, MD; ${ }^{\dagger}$ Michael Bullard, MD; \\ Eric Grafstein, MD; ${ }^{\S}$ Michael Schull, MD; ${ }^{\Uparrow \pi}$ Eddy Lang, MD; ${ }^{* *}$ Antoinette Colacone, BSc, CCRA; ${ }^{*}$ \\ Nathalie Soucy, PhD; ${ }^{*}$ Xiaoqing Xue, MSc; ${ }^{*}$ Eli Segal, MD*
}

\section{ABSTRACT}

Objective: Managers of emergency departments (EDs), governments and researchers would benefit from reliable data sets that characterize use of EDs. Although Canadian ED lists for chief complaints and triage acuity exist, no such list exists for diagnosis classification. This study was aimed at developing a standardized Canadian Emergency Department Diagnosis Shortlist (CED-DxS), as a subset of the full International Classification of Diseases, 10th revision, with Canadian Enhancement (ICD-10-CA). Methods: Emergency physicians from across Canada participated in the revision of the ICD-10-CA through 2 rounds of the modified Delphi method. We randomly assigned chapters from the ICD-10-CA (approximately 3000 diagnoses) to reviewers, who rated the importance of including each diagnosis in the ED-specific diagnosis list. If $80 \%$ or more of the reviewers agreed on the importance of a diagnosis, it was retained for the final revision. The retained diagnoses were further aggregated and adjusted, thus creating the CED-DxS.

Results: Of the 83 reviewers, $76 \%$ were emergency medicine (EM)-trained physicians with an average of 12 years of experience in EM, and $92 \%$ were affiliated with a university teaching hospital. The modified Delphi process and further adjustments resulted in the creation of the CED-DxS, containing 837 items. The chapter with the largest number of retained diagnoses was injury and poisoning $(n=292)$, followed by gastrointestinal ( $n=59)$, musculoskeletal $(n=55)$ and infectious disease $(n=42)$. Chapters with the lowest number retained were neoplasm $(n=18)$ and pregnancy $(n=12)$.

Conclusion: We report the creation of the uniform CED-DxS, tailored for Canadian EDs. The addition of ED diagnoses to existing standardized parameters for the ED will contribute to homogeneity of data across the country.

Keywords: diagnosis classification, emergency department, administration

\section{RÉSUMÉ}

Objectif : Les gestionnaires de services d'urgence, les gouvernements et les chercheurs auraient avantage à utiliser des ensembles de données fiables qui caractériseraient l'utilisation des services d'urgence. Bien que les urgences au Canada aient des listes de raisons de consultation et une échelle de triage et de gravité, elles ne disposent pas de telles listes pour la classification des diagnostics. Cette étude visait à dresser une liste abrégée et standardisée des diagnostics dans les services d'urgence au Canada (SUCan-DgA), comme sousensemble de la version élargie de la Classification internationale des maladies, $10^{\mathrm{e}}$ révision (CIM-10-CA) pour la classification au Canada.

Méthodes : Des médecins d'urgence des quatre coins du Canada ont participé à la révision de la liste CIM-10-CA par le biais de 2 rondes en appliquant une version modifiée de la technique Delphi. Nous avons assigné aléatoirement les chapitres de la liste CIM-10-CA (environ 3000 diagnostics) aux examinateurs, qui ont évalué l'importance de l'inclusion de chaque diagnostic dans une liste de diagnostics propres aux services d'urgence. Lorsque $80 \%$ ou plus des examinateurs s'entendaient sur l'importance d'un diagnostic, ce dernier était retenu pour la révision finale. Les diagnostics retenus ont ensuite été agrégés et ajustés pour dresser la liste SUCan-DgA.

Résultats : Parmi les 83 examinateurs, $76 \%$ étaient des médecins d'urgence dûment formés, comptant en moyenne 12 ans d'expérience en médecine d'urgence, et $92 \%$ étaient affiliés à un centre hospitalier universitaire. L'utilisation de la technique Delphi modifiée et des ajustements subséquents ont permis la création d'une liste SUCan-DgA renfermant 837 éléments. Le chapitre dont on a retenu le plus grand nombre de diagnostics était celui des blessures et des empoisonnements ( $n=292$ ), suivi de ceux des maladies gastro-intestinales ( $n=59)$, des maladies musculosquelettiques $(n=55)$ et des maladies

From the *Emergency Multidisciplinary Research Unit and the †Centre for Clinical Epidemiology and Community Studies, Jewish General Hospital, McGill University, Montréal, Que., ‡University of Alberta Hospital, University of Alberta, Edmonton, Alta., §St. Paul's Hospital, University of British Columbia, Vancouver, BC, ๆSunnybrook Health Sciences Centre and Institute for Clinical Evaluative Sciences, University of Toronto, Toronto, Ont., and ${ }^{* *}$ Alberta Health Services, University of Calgary, Calgary, Alta.

Submitted Mar. 6, 2009; Revised Oct. 9, 2009; Accepted Oct. 23, 2009

This article has been peer reviewed.

CJEM 2010;12(4):311-9 
infectieuses ( $n=42)$. Les chapitres pour lesquels on a retenu le moins grand nombre de diagnostics étaient ceux de l'oncologie $(n=18)$ et de l'obstétrique $(n=12)$.

Conclusion : Nous signalons la création d'une liste SUCan-DgA standardisée adaptée aux services d'urgence au Canada. L'ajout d'une liste de classification des diagnostics aux paramètres standardisés existants pour les services d'urgence contribuera à l'homogénéisation des données partout au pays.

\section{INTRODUCTION}

The combination of high patient volumes and rising numbers of admitted patients being held or boarded in the emergency department (ED) have led to significant increases in ED lengths of stay. An accurate description of patients seeking ED medical care is essential to the understanding of ED use and function. ${ }^{1,2}$ Many jurisdictions are beginning to develop policies to improve access to ED care and are moving toward gathering of populationbased ED data. ${ }^{3}$ Patient chief complaint, triage acuity score and diagnosis (provisional and final ED discharge diagnoses) are core elements that assist in characterizing the burden of illnesses managed in Canadian EDs. ${ }^{4-7}$ The Canadian Emergency Department Information System (CEDIS) Presenting Complaint List and the Canadian Emergency Department Triage and Acuity Scale (CTAS) are the national standards for these data elements. Although ED-specific standard diagnostic lists have been developed in other countries-13 tailored to their specific clientele and following their local classification rules, there is currently no standard diagnosis list for Canadian EDs that can be easily used in real time. ${ }^{4}$

Several organizations such as the CEDIS National Working Group, the Canadian Institute for Health Information (CIHI), the Ministère de la Santé et des Services Sociaux (MSSS, Quebec Health Ministry) and other provincial health ministries have each developed data sets that characterize ED use. ${ }^{14,15}$ Although all of these data sets include diagnosis as a mandatory element, the lack of a common national ED-specific diagnosis list makes comparative analyses difficult.

The International Classification of Diseases, 10th revision, with Canadian Enhancement (ICD-10-CA, 2003 version) contains 14203 diagnoses and is the gold standard for diagnostic coding. Using the full ICD list in real time in EDs, however, is not cost-effective, functional or practical. ${ }^{1,16}$ In Ontario and Alberta, the CIHI requires professional codification of each emergency visit using the full ICD-10-CA. The shortage of health information managers (medical archivists) in Canada presents an important barrier to implementing this policy across the country. ${ }^{17-20}$ Coding emergency visits using retrospective chart reviews after the patient visits has not been shown to be more accurate than prospective physician-aided coding. ${ }^{21-26}$ Gorelick and coauthors ${ }^{27}$ note that although a majority of diagnoses derived from clinical or administrative sources fall within the diagnostic group, it is not clear which should be considered the gold standard.

The objective of this project was to develop a Canadian Emergency Department Diagnosis Shortlist (CED-DxS), as a subset of the full ICD-10-CA. The CED-DxS could be used to organize ED databases, be accessed and applied by ED personnel, and permit the collection of diagnostic information in real time.

\section{METHODS}

The study used consensus process and expert revision involving emergency physicians from across Canada in the development of a standardized CED-DxS. The study received approval from the research ethics review committee of the Jewish General Hospital.

\section{Selection of expert reviewers}

This pan-Canadian project was designed to assure an adequate cross-sectional representation of emergency medicine (EM) physicians from across the country. Emergency medicine physicians were identified through their work in academia and/or research and were contacted by email. They were asked to recommend 5 EM physicians within their region, urban or rural, at least 2 of whom were pediatric care providers, who would be interested in participating in the research. This process identified 103 emergency physicians, of which $83(81 \%)$ participated in the study.

\section{Review process of the ICD-10-CA}

The review process consisted of 5 phases. In the first phase, a modified Delphi method ${ }^{22-30}$ with 2 rounds was employed to select the individual diagnoses that should be included in the CED-DxS from within the 14 203item ICD-10-CA list. Reviewers, working independently, were assigned randomly selected chapters from the ICD-10-CA with approximately 3000 diagnoses to 
assess. This resulted in each diagnosis being assessed by an average of 14 reviewers (range 13-16). An interactive computer spreadsheet using Excel 2003 (Microsoft Corp.) was developed to facilitate each reviewer's completion of the survey.

Reviewers were asked to rate the importance of including each diagnosis within an ideal CED-DxS. The rating was conducted using a 4-point Likert scale ( 1 = not important, 2 = minimally important, 3 = important, 4 = very important). The instructions sent to the reviewers indicated that the list was being built for clinical usage, administrative research and quality assurance purposes. Reviewers were informed that the selection of items should not be detailed to the point where it would become cumbersome to use prospectively in the ED. The reviewer responses were then dichotomized into not important (1 and 2) versus important (3 and 4$)$. In round 1 of the modified Delphi, any items that were rated as important by $70 \%$ or more of the reviewers were retained for the next phase. In round 2 of the modified Delphi, those diagnoses that did not achieve a strong general consensus $(50 \%-69 \%)$ and those that had achieved a consensus ( $\geq 70 \%$ ) only among reviewers based in pediatric EM were then sent out again for re-evaluation.

The second phase consisted of an analysis of nonselected diagnoses from the initial selection process (Delphi rounds 1 and 2). Diagnoses that had been rejected during the first 2 rounds were aggregated by the investigators into a less-specific diagnosis within their category or into other broader related diagnoses outside their category. The aggregated diagnoses that reached a consensus of $70 \%$ or more were retained. As an example, none of the following 9 diagnoses reached the required threshold: retinopathy of prematurity, other proliferative retinopathy, degeneration of macula and posterior pole, peripheral retinal degeneration, hereditary retinal dystrophy, retinal hemorrhage, separation of retinal layers, other specified retinal disorders. However, when these diagnoses were aggregated together into "retinal disorder, nonspecified," it reached the threshold for retention.

During the third phase, the items selected as important by the reviewers and retained after the first 2 phases were adjudicated by the investigators to ensure that no relevant diagnoses were excluded and to correct for redundancies (e.g., dementia and Alzheimer disease). The first 3 phases led to the development of a "detailed" ED diagnosis list. The fourth phase created a more concise short list by increasing the consensus threshold percentage to $80 \%$ or greater to make the list comparable in length (i.e., 600-900 items) with other existing short lists of diagnoses. This was accomplished by following the same method as the previous phases. The fifth phase created the CED-DxS with the assistance of CIHI. This last phase included maintaining consistency within the injury diagnoses (e.g., open wounds, contusions, fractures) and further eliminating redundancies.

Data management and analyses were conducted using Excel 2003, Access 2003 (Microsoft Corp.) and SAS v9.1 (SAS Institute Inc.).

\section{RESULTS}

\section{Reviewers}

Of the 83 reviewers, $76 \%$ were EM specialists certified through either the Royal College of Physicians and Surgeons of Canada, or The College of Family Physicians of Canada, and 28\% served as ED directors (Table 1).

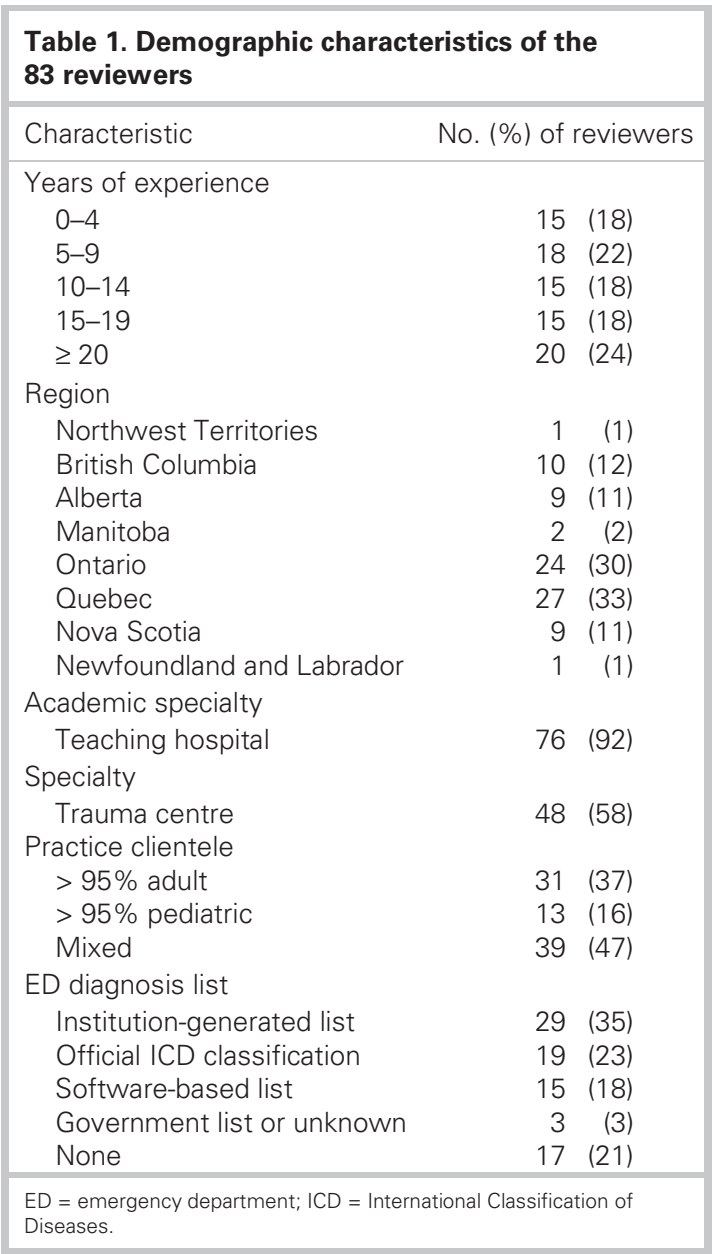


The reviewers averaged 12 years of EM experience, with $24 \%$ working for longer than 20 years in the field. Of the reviewers, $92 \%$ were affiliated with a university, $58 \%$ were based at a trauma centre, and $47 \%$ worked in EDs handling both pediatric and adult patients. Furthermore, $30 \%$ of the physicians worked in institutions that did not have a computerized ED information system, 35\% used an "institution-generated" diagnosis list and $21 \%$ had no diagnosis list at all.

\section{Derivation of diagnostic list}

Figure 1 represents the flow diagram of the review process and results of the different phases. In phase 1 , the Delphi round 1 identified 1201 diagnoses achieving a $70 \%$ or greater level of consensus among reviewers. There were 1990 diagnoses that achieved a threshold of $50 \%-69 \%(n=1378)$ or a consensus of $70 \%$ or greater $(n=612)$ only among reviewers based in pediatric EM. These were then submitted to a second Delphi round, with $57(69 \%)$ reviewers completing the process. This produced an additional 37 diagnoses using the criterion $70 \%$ or greater selection threshold.

The second phase identified another 202 diagnoses that resulted from the aggregation of multiple diagnoses. The third phase resulted in the removal of

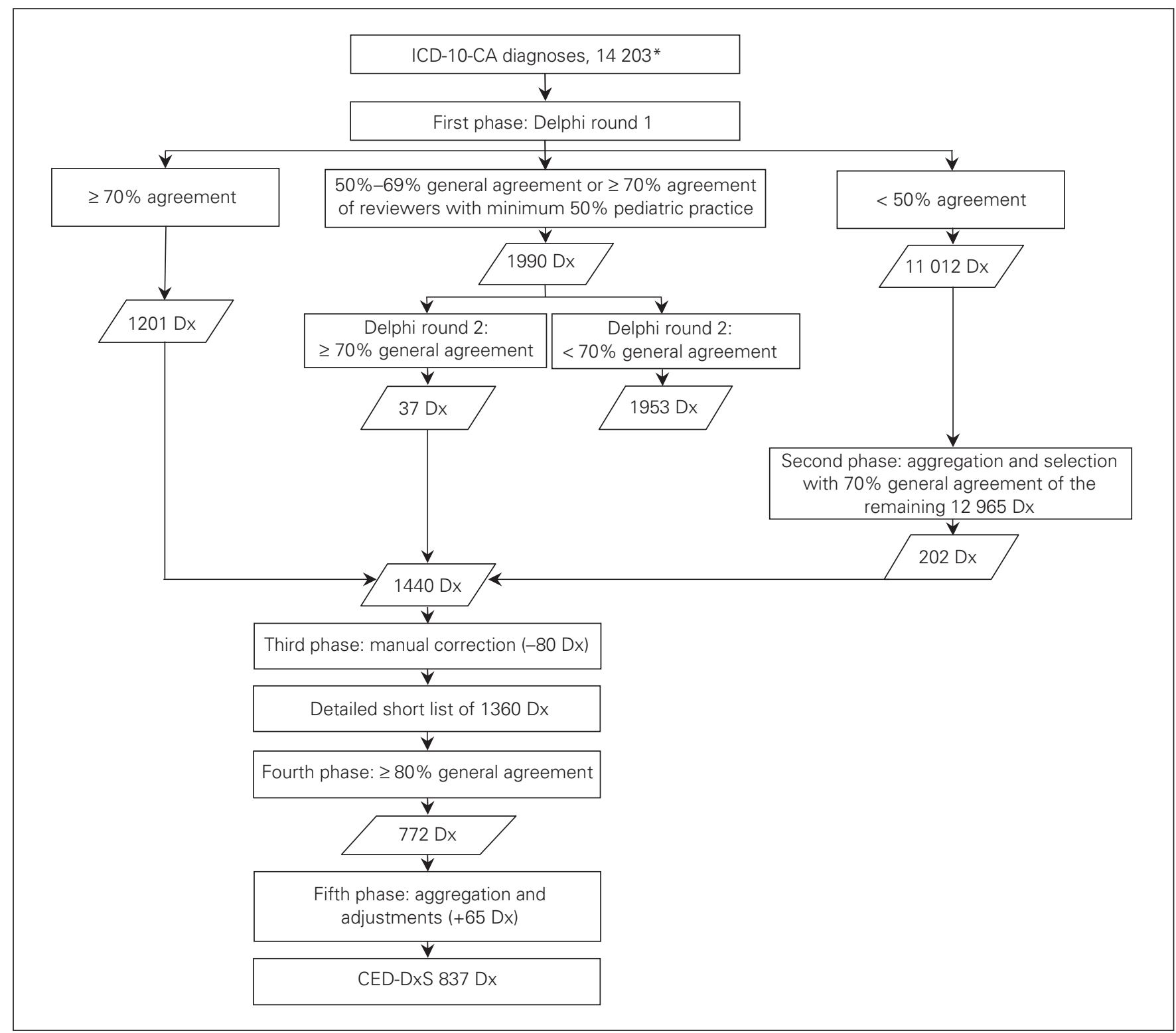

Fig. 1. Flow diagram of the review process of the International Classification of Diseases, 10th revision, with Canadian Enhancement (ICD-10-CA). *Based on 2003 version of ICD-10-CA (minus chapter 20). Dx = diagnoses. 
80 diagnoses that were redundant as they were repeated in different chapters. This process resulted in the creation of a "detailed" ED diagnosis list containing 1360 ED diagnoses.

Existing Canadian and international ED diagnosis lists contain 500 to 900 diagnoses, ${ }^{8,9,30}$ which suggests that a more concise list is desirable in the ED. This requires striking a balance between functionality, the ability to use in real time, and sufficient detail to describe the diagnoses of most patients. Therefore, in phase 4 , the level of reviewer selection consensus was increased to $80 \%$ or greater to retain a diagnosis. Furthermore, to be able to cover all diagnoses included in the detailed list, those that did not reach the $80 \%$ threshold were aggregated into less-specific categories for each diagnostic concept (Table 2). During this process, investigators also collaborated with representatives from CIHI and the MSSS to further refine and finalize the concise list. Although the initial goal was to create a list of 700 items, the entire process culminated in the creation of the CED-DxS list containing $837 \mathrm{ED}$ diagnoses. To facilitate ED implementation of the CED-DxS list, the ICD-10-CA descriptions were supplemented by commonly used English and French medical nomenclature (Table 3 ).

\begin{tabular}{|c|c|c|c|}
\hline Dx code & ICD-10-CA description & $\begin{array}{l}\text { Detailed } \\
\text { list }\end{array}$ & CED-DxS \\
\hline 121.0 & $\begin{array}{l}\text { Acute transmural myocardial } \\
\text { infarction of anterior wall }\end{array}$ & Yes & \\
\hline I21.1 & $\begin{array}{l}\text { Acute transmural myocardial } \\
\text { infarction of inferior wall }\end{array}$ & Yes & \\
\hline $\mid 21.2$ & $\begin{array}{l}\text { Acute transmural myocardial } \\
\text { infarction of other sites }\end{array}$ & & \\
\hline 121.3 & $\begin{array}{l}\text { Acute transmural myocardial } \\
\text { infarction of unspecified site }\end{array}$ & Yes & \\
\hline 121.4 & $\begin{array}{l}\text { Acute subendocardial myocardial } \\
\text { infarction }\end{array}$ & & \\
\hline 121.40 & $\begin{array}{l}\text { Acute subendocardial myocardial } \\
\text { infarction of anterior wall }\end{array}$ & & \\
\hline |21.41 & $\begin{array}{l}\text { Acute subendocardial myocardial } \\
\text { infarction of inferior wall }\end{array}$ & & \\
\hline 121.42 & $\begin{array}{l}\text { Acute subendocardial myocardial } \\
\text { infarction of other sites }\end{array}$ & & \\
\hline 121.49 & $\begin{array}{l}\text { Acute subendocardial myocardial } \\
\text { infarction, unspecified site }\end{array}$ & Yes & \\
\hline 121.9 & $\begin{array}{l}\text { Acute myocardial infarction, } \\
\text { unspecified }\end{array}$ & Yes & Yes \\
\hline
\end{tabular}

Table 4 displays the number of diagnoses retained for the CED-DxS $(n=837)$ from each chapter. The chapter with the largest number of retained items was injury, poisoning and consequences of external causes $(n=$ 292). This was followed by the gastrointestinal diagnoses $(n=59)$ and musculoskeletal $(n=55)$. Chapters neoplasm $(n=18)$ and pregnancy $(n=12)$ supplied the lowest number of diagnoses retained.

The CED-DxS $(n=837)$ list is available at the CIHI National Ambulatory Care Reporting System website (http://secure.cihi.ca/cihiweb/dispPage.jsp?cw_page= services_nacrs_e). Users will require a prior license for the ICD-10-CA to download and use the list.

\section{DISCUSSION}

This project developed an ED-specific diagnosis short list with 837 items, as a subset of the full ICD-10-CA. These lists were created through the expert consultation of EM physicians from across Canada. Moreover, the authors have worked with representatives from $\mathrm{CIHI}$ and the MSSS to ensure widespread adoption.

Before this project, there was no standardized Canadian ED diagnosis list. ${ }^{4}$ Although locally generated ED diagnosis lists exist, the lack of uniformity results in different labels for the same medical entities across the country. Other countries, such as Australia and France, have developed their own ED-specific lists. ${ }^{8-13}$ Although these lists contain significant overlap with each other, they also differ substantially, rendering them unique to their own national settings and needs. Other countries are also developing ED-specific diagnosis shortlists that match their own patient populations and needs. The

Table 3. Examples of common emergency department terms

\begin{tabular}{lc}
\hline ICD-10-CA description & \multicolumn{1}{c}{ ED terms } \\
\hline $\begin{array}{l}\text { Respiratory tuberculosis unspecified, } \\
\text { without mention of bacteriological or }\end{array}$ & TB, tuberculosis \\
histological confirmation & \\
$\begin{array}{l}\text { Unspecified viral infection } \\
\text { characterized by skin and mucous }\end{array}$ & Exanthema, viral \\
membrane lesions & \\
$\begin{array}{l}\text { Injury of unspecified muscle and } \\
\text { tendon at wrist and hand level; other }\end{array}$ & Inj. muscle/tendon \\
$\begin{array}{l}\text { and unspecified injury } \\
\text { Preterm delivery, delivered, with or }\end{array}$ & hand/wrist \\
without mention of antepartum & Preterm delivery \\
condition & \\
$\begin{array}{l}\text { Syndrome of inappropriate secretion } \\
\text { of antidiuretic hormone }\end{array}$ & SIADH \\
\hline $\begin{array}{l}\text { ED = emergency department; ICD-10-CA = International Classification of Diseases, } \\
\text { 10th revision, with Canadian Enhancement. }\end{array}$
\end{tabular}


CED-DxS is the first ED diagnosis list developed specifically for Canadian EDs.

There were several possible methods to develop a Canadian diagnosis short list. Among these included the compilation of short lists already used across Canada, a compilation of billing records from all the provinces, or an adaptation of other diagnosis short lists. For this study, we used the modified Delphi approach with a pan-Canadian survey to develop an ED diagnosis short list from the standardized ICD-10-CA. This method has the advantage of obtaining input from a geographically dispersed group of EM experts and also reducing the effects of bias due to group interaction. Moreover, the involvement of the EM community in Canada was fundamental to the development of CED-DxS and will help foster its acceptance throughout the country.

Previous research has shown that there is poor interrater reliability when very detailed levels of information are requested, and better interrater reliability is obtained when data are aggregated. ${ }^{12}$ Moreover, Nilsson and colleagues ${ }^{1}$ described the difficulties in selecting the level of aggregation when developing a tool. Aggregation was required in situations in which specific diagnoses are difficult to assign in the ED before they are clearly confirmed. For example, "abdominal pain" is a more appropriate diagnosis for undifferentiated pain than "biliary colic" when there is no clear evidence for that diagnosis.

To achieve an acceptable level of interrater reliability, the amount of detail needs to be weighed against the functionality of the list when used prospectively by ED staff. Initially, a selection consensus of $70 \%$ or greater among reviewers plus a certain level of aggregation by the research team were used to ensure adequate detail while balancing efficiency. This produced a list of 1360 items (Fig. 1) that, when compared with other existing institutional-based ED diagnosis lists (median 700), was still considered too long to be functional. Agreement was then increased to $80 \%$ and, with further aggregation, the final concise CED-DxS of 837 items was derived. Although this list was still over our original goal of 700, as in any short list, the CED-DxS cannot cover the whole range of diagnostic possibilities. Although the CED-DxS loses detail compared with the list of 1360 items, it compensates by offering greater simplicity and ease of use. This will facilitate the adoption of the standardized concise CED-DxS in EDs across the country.

\begin{tabular}{|c|c|c|c|c|}
\hline \multirow{2}{*}{$\begin{array}{l}\text { Chapter } \\
\text { no. }\end{array}$} & \multirow[b]{2}{*}{ Chapter description } & \multicolumn{2}{|c|}{ No. of diagnoses } & \multirow[b]{2}{*}{$\%$ of CED-DxS } \\
\hline & & ICD-10-CA, $n=14203$ & CED-DxS, $n=837$ & \\
\hline 1 & Certain infectious and parasitic diseases & 763 & 42 & 5.0 \\
\hline 2 & Neoplasm & 803 & 18 & 2.2 \\
\hline 3 & Diseases of the blood and blood-forming organs/immune & 169 & 9 & 1.1 \\
\hline 4 & Endocrine, nutritional and metabolic diseases & 1060 & 29 & 3.5 \\
\hline 5 & Mental and behavioural disorders & 409 & 21 & 2.5 \\
\hline 6 & Diseases of the nervous system & 398 & 34 & 4.1 \\
\hline 7 & Diseases of the eye and adnexa & 277 & 19 & 2.3 \\
\hline 8 & Diseases of the ear and mastoid process & 117 & 13 & 1.6 \\
\hline 9 & Diseases of the circulatory system & 408 & 45 & 5.4 \\
\hline 10 & Diseases of the respiratory system & 245 & 33 & 3.9 \\
\hline 11 & Diseases of the digestive system & 456 & 59 & 7.0 \\
\hline 12 & Diseases of the skin and subcutaneous tissue & 365 & 24 & 2.9 \\
\hline 13 & Diseases of the musculoskeletal system and connective tissue & 2593 & 55 & 6.6 \\
\hline 14 & Diseases of the genitourinary system & 477 & 34 & 4.1 \\
\hline 15 & Pregnancy, childbirth and the puerperium & 1242 & 12 & 1.4 \\
\hline 16 & Certain conditions originating in the perinatal period & 338 & 12 & 1.4 \\
\hline 17 & Congenital malformations, deformations and chromosomal abn. & 634 & 5 & 0.6 \\
\hline 18 & Symptoms, signs and abnormal clinical and laboratory findings & 353 & 57 & 6.8 \\
\hline 19 & Injury, poisoning and consequences of external causes & 2389 & 292 & 34.9 \\
\hline 21 & Factors influencing health status and contact with health services & 684 & 23 & 2.7 \\
\hline 23 & Provisional codes for research and temporary assignment & 23 & 1 & 0.1 \\
\hline
\end{tabular}


The lack of common ED data elements in Canada has presented difficulties with conducting multicentred research, and with governmental reporting. This common template for data collection will complement the existing standardized chief complaint and triage elements. Furthermore, it will address the need to provide greater clarity and consistency in the characterization of ED patients, facilitating research, aiding in syndrome surveillance ${ }^{13,31}$ and assisting key stakeholders in management of emergency operations.

\section{Limitations}

The selection of expert reviewers was intended to capture a representative sample of EM physicians from a variety of practice settings, including rural and primary EDs. However, we obtained responses and reviewer commitments mostly from academic emergency physicians, which resulted in an underrepresentation of rural sites. This could result in the exclusion of certain diagnoses that are seen only in more community and rural EDs in Canada. This will need to be addressed in the future revisions of the list. In addition, reviewers were asked to evaluate only parts ( 3000 diagnoses) of the ICD-10-CA instead of the entire list (14 203 diagnoses). Although it would have been ideal to have reviewers evaluate the entire ICD-10-CA, this was not feasible. Nevertheless, diagnosis chapters were randomly assigned to prevent the review of each chapter by the same group of reviewers.

The reviewers chose diagnoses based on the ICD10-CA list. On review of the list generated by reviewers, it was noted that there was a handful of common emergency-based diagnoses that do not exist as such in the ICD-10-CA (e.g., radial head subluxation) that required an adjustment of the common language definitions to accommodate these items.

The reduction of the original ICD-10-CA into a list of 837 required certain adjustments, such as the elimination of redundancies. Although the majority (92\%) of the items selected was retained through the modified Delphi process, the final list included diagnoses retained at the suggestion of the reviewers of the final list from the research team, CIHI and the MSSS. Some of this process included nonconsultative phases and may have been subject to the biases of the research team. The 2003 version of the ICD-10-CA was used in this study, and since then more refined diagnoses and additional alphanumeric codes have been developed. An adjustment of the alphanumeric codes and nomencla- ture was required to comply with the 2009 version of the ICD-10-CA. Finally, this coding system has never been applied in clinical practice and its reliability and validity is unknown.

\section{Future directions}

Future research may address the feasibility of implementation of CED-DxS within different EDs and its use for policy-making, management and research. Reliability related to the use of CED-DxS by variable personnel such as physicians, nurses, clerical staff and nosologists needs to be documented in multiple settings before widespread application.

The CED-DxS will require further refinement after usage and will result in the development of further editions in the years to come.

Acknowledgements: Special thanks to Ms. Ruth Léger, RN, for her diligence in coordinating the collection of data and to Dr. Alain Vadeboncoeur (Institut cardiologie de Montréal), Dr. Jean Marc Chauny (Hôpital Sacré Coeur), Dr. Julien Poitras (Hôtel-Dieu de Lévis), Dr. Jocelyn Gravel (CHU Ste. Justine), Dr. Emmanuelle Jourdenais (CH de l'Université de Montréal), Ms. Sylvie Berger (MSSS), CIHI and the CEDIS committee for their input.

\section{Competing interests: None declared.}

Funding: This study was funded by the Canadian Institutes of Health Research, and supported by a team grant from the Fonds de la Recherche en Santé du Québec.

\section{REFERENCES}

1. Nilsson G, Petersson H, Ahlfeldt H, et al. Evaluation of three Swedish ICD-10 primary care versions: reliability and ease of use in diagnostic coding. Methods Inf Med 2000;39:325-31.

2. Building on values. The future of health care in Canada. Commission on the Future of Health Care in Canada. Ottawa (ON): National Library of Canada; 2002. Available: www.cbc.ca /healthcare/final_report.pdf (accessed 2008 Mar. 2).

3. Coonan KM. Medical informatics standards applicable to emergency department information systems: making sense of the jumble. Acad Emerg Med 2004;11:1198-205.

4. Innes G, Murray M, Grafstein E; for the Canadian Emergency Department Information System (CEDIS) working group. A consensus-based process to define standard national data elements for a Canadian emergency department information system. CJEM 2001;3:277-84.

5. Grafstein E, Unger B, Bullard M, et al.; for the Canadian Emergency Department Information System working group. Canadian Emergency Department Information System (CEDIS) Presenting Complaint List (Version 1.0). CJEM 2003;5:27-34. 
6. Grafstein EJ, Bullard MJ, Warren D, et al. Revision of the Canadian Emergency Department Information System (CEDIS) Presenting Complaint List (Version 1.1). CJEM. 2008;10:151-61.

7. Bullard MJ, Unger B, Spence J, et al. Revisions to the Canadian Emergency Department Triage and Acuity Scale (CTAS) adult guidelines. CJEM. 2008;10:136-42.

8. Health data standards \& systems in Victorian hospitals. Victorian emergency minimum dataset (VEMD). State Government of Victoria, Australia, Department of Human Services; 2010. Available: www.health.vic.gov.au/hdss/vemd/index.htm (accessed 2008 Jun. 29).

9. Lestavel P, Smaiti N; pour la SFMU et la commission d'évaluation. Le Thésaurus de Médecine d'Urgence 2001. Paris (France): Service d'accueil et de traitement des urgences CHRU LILLE; 2000. Available: www.sfmu.org/fr/ressources /referentiels (accessed 2008 Jun. 29).

10. Smedby B. Comparison of current shortlist used for OECD data collection with the new Eurostat shortlist. Brussels (Belgium): European Commission; 2010. Available: www.ec.europa.eu/health/ph_information/dissemination/hsis /hospital_4.pdf (accessed 2008 Jun. 29).

11. Emergency department classifications update. Coding Matters: Newsletter of the National Centre for Classification in Health 2002;9(2):1-35.

12. Britt H, Angelis M, Harris E. The reliability and validity of doctor-recorded morbidity data in active data collection systems. Scand J Prim Health Care 1998;16:50-5.

13. Begier EM, Sockwell D, Branch LM, et al. The National Capitol Region's emergency department syndromic surveillance system: Do chief complaint and discharge diagnosis yield different results? Emerg Infect Dis 2003;9:393-6.

14. National Ambulatory Care Reporting System (NACRS). Ottawa (ON): Canadian Institute for Health Information; 2007. Available: www.cihi.ca/cihiweb/en/downloads/nacrs_exec _summ_2008_2009_e.pdf (accessed 2010 May 21).

15. Afilalo M, Berger S, Hamel $\mathrm{P}$, et al. Guide de gestion de l'unité d'urgence. Québec (QC): Association des hôpitaux de Québec et Comité d'experts du groupe de coordination nationale des urgences du Québec, MSSS; 2000. Available: www.amuq.qc.ca /AxisDocument.aspx? id=14\&langue=fr\&download=true \&doc ument=Guide\%20de\%20gestion\%20de\%201 (accessed 2008 Mar. 23).

16. Parnanen H, Kumpusalo E, Takala J. Primary health care ICD-a tool for general practice research. Int 7 Health Plann Mgmt 2000;15:133-48.

17. Jolicoeur M. Un grand sous-traitant américain de services aux hôpitaux s'installe à Montréal. Les affaires 2008 Jan 26; p. 11.

18. Moskal L. The implementation of ICD-10-CA and CCI in Canada. American Health Information Management Association; 2004. Available: http://library.ahima.org/xpedio/groups /public/documents/ahima/bok3_005526.hcsp?dDocName=b ok3_005526 (accessed 2008 May 15).

19. Meyers S. Coder shortage goes straight to the bottom line. Chicago (IL): Hospital and Health Networks; 2004. Available: www.hhnmag.com/hhnmag_app/hospitalconnect/search /article.jsp?dcrpath=AHA/PubsNewsArticle/data/0401 HHN FEA_Workforce\&domain=HHNMAG (accessed 2008 Jan. 31).
20. Health informatics and bealth information management: buman resources report. Toronto (ON): Prism Economics and Analysis; 2009.

21. Muscatello D, Travis S. Using the international classification of diseases with HOIST. NSW Public Health Bull 2001; 12:289-93.

22. Smith MW. Hospital discharge diagnoses: How accurate are they and their international classification of diseases (ICD) codes? NZ Med J 1989;102:507-8.

23. O'Malley KJ, Cook KF, Price MD, et al. Measuring diagnoses: ICD code accuracy. Health Serv Res 2005;40:1620-39.

24. Yao P, Wiggs BR, Gregor C, et al. Discordance between physicians and coders in assignment of diagnoses. Int 7 Qual Health Care 1999;11:147-53.

25. Bota GW, Therrien SA, Rowe BH. A truncated E-code system for injury surveillance in the emergency department: description and clinometric testing. Acad Emerg Med 1997;4:291-6.

26. Edmeston JT, Craib K, Djurdjev O, et al. The reliability of diagnostic codes used in a customized in house emergency medicine database - the New Emergency Resource Database (NERD). CJEM 1999;1:169-70.

27. Gorelick MH, Knight S, Alessandrini EA, et al. Pediatric Emergency Care Applied Research Network. Lack of agreement in pediatric emergency department discharge diagnoses from clinical and administrative data sources. Acad Emerg Med 2007;14:646-52.

28. Fink A, Kosecoff J, Chassin M, et al. Consensus methods: characteristics and guidelines for use. Am 7 Public Health 1984;74:979-83.

29. Campbell SM, Hann M, Roland MO, et al. The effect of panel membership and feedback on ratings in a two-round Delphi survey: results of a randomized controlled trial. Medical Care 1999;37:964-8.

30. Lindsay P, Schull M, Bronskill S, et al. The development of indicators to measure the quality of clinical care in emergency departments following a modified-Delphi approach. Acad Emerg Med 2002;9:1131-9.

31. Fleischauer AT, Silk BJ, Schumacher M, et al. The validity of chief complaint and discharge diagnosis in emergency department-based syndromic surveillance. Acad Emerg Med 2004;11:1262-7.

Correspondence to: Dr. Bernard Unger, Emergency Department, McGill University, Rm. D-010, Jewish General Hospital, 3755 Cote Ste. Catherine Rd., Montréal QC H3T 1E2; bernard.unger@mcgill.ca

The reviewers of the ICD-10-CA diagnoses: Alberta Children's Hospital, Calgary, Alta.: Belanger F., Millar K.; BC Children's Hospital, Vancouver, BC: Clarke M., Colbourne M., Haughton D., Hung G., Whitehouse S.; Cape Breton Regional Hospital, Sidney, NS: Currie T.; Children's Hospital of Eastern Ontario, Ottawa, Ont.: Farion K.; CH de l'Université de Montréal, Montréal, Que.: Desaulniers P., Boulet M., Charbonneau L., Laurens J.P., Jourdenais E.; CH de l'Université de Québec-Pavillon CHUL, Québec, Que.: Bernier D., Germain V., Guimont C., Nazair P., Turgeon R.; Colchester 
Regional Hospital, Truro, NS: Howlett M.; Credit Valley Hospital, Mississauga, Ont.: Humniski A.M., Letovsky E., Scampoli N.; CSSS de Gatineau, Gatineau, Que.: Folot M.H., Forest G., Michaud M.N., Pham Dinh M., Sibille P.; Foothills Medical Centre, Calgary, Alta.: Wertzler B.; Greater Niagara General Hospital, Niagara Falls, Ont.: Turineck D.; Grey Nuns Comm. Hospital \& Health Centre, Edmonton, Alta.: Kruhlak R.; Hamilton Health Sciences, Hamilton, Ont.: Upadhye S., Rutledge G.; Health Sciences Centre Winnipeg, Winnipeg, Man.: Sweetland R.; Hôpital Maisonneuve Rosemont, Montréal, Que.: Mathieu B.; Hôpital Sacré Coeur, Montréal, Que.: Chauny J.M.; Hospital for Sick Children, Toronto, Ont.: Guttmann A.; Hôtel Dieu de St-Jérôme, St-Jérôme, Que.: Gosselin M.; Hôtel-Dieu de Lévis, Lévis, Que.: Poitras J.; HotelDieu Grace Hospital, Windsor, Ont.: Bradford P.; Institut cardiologie de Montréal, Montréal, Que.: Vadeboncoeur A.; IWK Health Centre, Halifax, NS: Sinclair D., Taylor B.; Kingston General Hospital, Kingston, Ont.: Blouin D., Dagnone G., Dungey P., Edwards K.; Kitchener-Waterloo Health System, Kitchener, Ont.: Kolleck D.; Lake of the Woods District Hospital, Kenora, Ont.: Moore S.; Lakeridge Health, Oshawa, Ont.: Vandersluis R.; Markham Stouffville Hospital, Markham,
Ont.: Austin D.; Mount Sinai Hospital, Toronto, Ont.: Ovens H.; MUHC-Montreal Children's Hospital and the Montreal General Hospital, Montréal, Que.: Nemeth J., Troquet J.M.; Prince George Regional Hospital, Prince George, BC: Rowe P.; Queen Elizabeth II Health Science Center, Halifax, NS: Magee K., Campbell S., Maxwell D., Murray J., Watson ML.; Royal Alexandra Hospital, Edmonton, Alta.: Dong K., Dong S., Rabin E.; MUHC - Royal Victoria Hospital, Montréal, Que.: Beique M.; Jewish General Hospital, Montréal, Que.: Dankoff J., Grad W., Stern E., Turner J.; St. Michael's Hospital, Toronto, Ont.: Cass D., Spence J.; St.Paul's Hospital, Vancouver, BC: Berringer R.; Stanton Territorial Hospital, Yellowknife, NWT: Hoechsmann A; Stollery Children's Hospital, Edmonton, Alta.: Turner T., Dong K.; St. John's Health Sciences Centre, St. John's, NL: Morgan D.; The Ottawa Hospital, Ottawa, Ont.: Calder L., Nussbaum C.; Thunder Bay Regional Hospital, Thunder Bay, Ont.: Visser S.; Toronto East General Hospital, Toronto, Ont.: Tyberg J.; University of Alberta Hospital, Edmonton, Alta.: Yao R., Dong S.; Vancouver General Hospital, Vancouver, BC: McKnight D., Moser M.; Victoria General \& Royal Jubilee, Victoria, BC: Wheeler S.; Winnipeg Children's Hospital, Winnipeg, Man.: Warda L.

\section{LOOKING FOR A NEW JOB?}

In print and online, the best way to advertise or find employment opportunities in academic, administrative or community emergency medicine is through the Canadian Journal of Emergency Medicine.

Print version of CJEM: The deadline for advertising in the print version of $C J E M$ is one month before issue date. For ad rates and further information, please contact Journal Advertising (800 663-7336 or 613 731-8610, advertising@cma.ca).

\section{LOOKING FOR AN EMERG DOc?}

\section{SPECIAL BONUS: As a bonus to print advertisers, $C J E M$ is pleased to offer website advertising space on CAEP's website (www.caep.ca) free of charge.}

CAEP website alone: Advertising in the CAEP website alone is billed at a rate of $\$ 100$ a month, and can be obtained at any time. Please contact CAEP's Head Office for advertising solely on the website (800 463-1158 or advertising@caep.ca). 